\title{
Intra- and Intergeneric Similarities of the Ribosomal Ribonucleic Acid Cistrons of Acetobacter and Gluconobacter
}

\author{
M. GILLIS* AND J. DE LEY \\ Laboratorium voor Microbiologie en microbiële Genetica, Rijksuniversiteit, Ledeganckstraat 35, B-9000 \\ Gent, Belgium
}

\begin{abstract}
Hybrids between ${ }^{14} \mathrm{C}$-labeled ribosomal ribonucleic acid (rRNA) from either Gluconobacter oxydans subsp. oxydans NCIB 9013, Acetobacter aceti subsp. aceti NCIB 8621t $\mathrm{t}_{1}$, or Zymomonas mobilis subsp. mobilis ATCC 29191 and deoxyribonucleic acid (DNA) from acetic acid bacteria and representative strains of possibly related and other gram-negative bacteria were prepared. Each hybrid was described by two parameters: $T_{m(e)}$, the temperature at which $50 \%$ of the hybrid was denatured, and the percentage of rRNA binding, the amount of ${ }^{14} \mathrm{C}$ labeled rRNA (in micrograms) duplexed under stringent conditions per $100 \mu \mathrm{g}$ of filter-fixed homologous or heterologous DNA. Each taxon occupied a definite area on the rRNA similarity maps. Parameters of hybrids formed with rRNA from $G$. oxydans subsp. oxydans NCIB 9013 showed that the acetic acid bacteria consist of two separate but closely related groups corresponding to the genera Acetobacter and Gluconobacter. When compared with rRNA from $A$. aceti subsp. aceti NCIB $8621 \mathrm{t}_{1}$, both genera were indistinguishable, showing that there were many strains of Acetobacter whose rRNA cistrons are as different from the reference Acetobacter rRNA as from Gluconobacter rRNA. The rRNA cistrons of Acetobacter were more heterogeneous than these of Gluconobacter. The great similarities among the $T_{m(e)}$ 's of the heterologous hybrids and among the numerous phenotypic features stress that both genera are more closely related to each other than to any other genus. The parameters of the DNA:rRNA hybrids located the acetic acid bacteria as a separate branch in an rRNA superfamily consisting of Rhodopseudomonas, Beijerinckia, Agrobacterium, Rhizobium, some Spiril. lum species, and Paracoccus denitrificans. Parameters of hybrids formed with rRNA from $Z$. mobilis subsp. mobilis ATCC 29191 showed that the genus Zymomonas forms a separate branch in the same rRNA superfamily. We detected a number of misnamed organisms. "Acetobacter" aceti subsp. xylinum NCIB 4112, "Acetobacter" aceti subsp. orleanensis NCIB 6426, and "Acetobacter" lermae NRRL B-1810 belong in the genus Gluconobacter. "Gluconobacter" industrius IFO 3261, "Gluconobacter" dioxyacetonicus IAM 1814, "Gluconobac. ter" sp. strains A4.1 and M28, "Pseudomonas" melophthora NCPPB 461 and 462, and "Pseudomonas" pomi NCPPB 463 are all regular members of Acetobacter. Our evidence is against the maintenance of "intermediate" strains of acetic acid bacteria. "Gluconobacter" liquefaciens NCIB 9505 and IAM 1834 and "G." melanogenus IAM 1835 and IAM 1836 are genetically regular members of the genus Acetobacter. "Acetobacter" aurantius IFO 3246 is a Gluconobacter. "A." aurantius IFO $3249,3247,13330$, and 13333 are not acetic acid bacteria at all. We propose to unite Acetobacter and Gluconobacter in the family Acetobacteraceae. The ranges of the moles percent guanine plus cytosine of the DNAs have been determined for the different taxa in both genera.
\end{abstract}

Bacterial ribosomal ribonucleic acid (rRNA) cistron similarities (expressed as the midpoint of the thermal denaturation curve $\left[T_{m(e)}\right]$ and the percentage of rRNA binding of the deoxyribonucleic acid [DNA]:rRNA hybrids) are valuable parameters for revealing taxonomic relatedness at the generic and suprageneric levels, for detecting misnamed taxa, and for identifying unknown isolates $(16,19)$. There seemed to be a distinct correlation between the thermal stability of heterologous DNA:rRNA hybrids, ex-

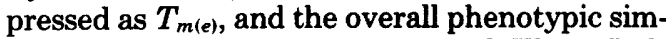
ilarities of the organisms concerned. These findings were discovered and explored in the Rhizobiaceae (19) and in Chromobacterium (16).

It is the purpose of the present paper to report the results of the application of this new method to an exploration of the internal taxonomic 
structure of the acetic acid bacteria Acetobacter and Gluconobacter and their relationship to each other and to other genera. This is part of an extensive genotypic and phenotypic study of these organisms in our laboratory. We also examined the similarity between the rRNA cistrons of the acetic acid bacteria and Zymomonas in view of the considerable phenotypic similarities between these genera (39).

\section{MATERIALS AND METHODS}

Bacterial strains and growth media. The strains used in this study are listed in Tables 1 and 2 under the names with which they were received. The acetic acid bacteria recently received from the National Collection of Industrial Bacteria (NCIB) were named according to the nomenclature used in Bergey's Man$u a l$, eighth edition (8). The bacteriological purity of all strains was checked by plating and by examining living and gram-stained cells. All petri dish cultures were incubated aerobically, except for the zymomonads, which were incubated anaerobically by the use of GasPak (BBL Microbiology Systems). Some strains as received displayed two different stable colony types $\left(t_{1}, t_{2}\right)$ upon plating; both were examined by polyacrylamide gel electrophoresis of their soluble proteins to differentiate between colony variants and contaminants (28). Either one or both types were used depending on the similarity of their electrophoregrams. For mass cultures, cells were grown as described before (19) except when stated otherwise. Zymomonads were grown without aeration at $28^{\circ} \mathrm{C}$ in $600 \mathrm{ml}$ of liquid medium Y (19) in 1-liter Erlenmeyer flasks. The compositions of some of the growth media used are summarized in Table 3. After growth, the cells were harvested, washed, and stored at $-12^{\circ} \mathrm{C}$ except for those of Acetobacter peroxydans and A. pasteurianus subsp. paradoxus, which were lysed immediately after harvesting.

Preparation of DNA. High-molecular-weight native DNA was prepared by the method described by Marmur (32). The final purification step was carried out through a $\mathrm{CsCl}$ gradient (16).

Fixation of single-stranded, high-molecularweight DNA on membrane filters. The procedure used for fixing single-stranded, high-molecular-weight DNA on membrane filters was that described by De Ley and Tytgat (17). Sartorius membrane filters SM 11309 were used. The DNA-containing filters were preserved at $4^{\circ} \mathrm{C}$ in vacuo (13).

Preparation of $\left[{ }^{14} \mathrm{C}\right] \mathrm{rRNA}$. Because the protein gel electrophoretograms of both colony types $t_{1}$ (dull) and $t_{2}$ (glistening) of NCIB 8621, the suggested neotype strain of Acetobacter aceti subsp. aceti, were nearly identical, we used $t_{1}$ for the preparation of ${ }^{14} \mathrm{C}$ labeled rRNA. From this strain and from NCIB 9013, the suggested neotype strain of Gluconobacter oxy. dans subsp. oxydans, $\left[{ }^{14} \mathrm{C}\right] \mathrm{RRNA}$ was prepared as previously described (19). We used medium $N$ (19) with a block of marble instead of powdery $\mathrm{CaCO}_{3}$. $\left[{ }^{14} \mathrm{C}\right] \mathrm{rRNA}$ from the phenotypic centrostrain Zymo. monas mobilis subsp. mobilis ATCC 29191 was prepared from $60 \mathrm{ml}$ of cell suspension from a culture grown without aeration in medium Y (19) containing
$30 \mu \mathrm{Ci}$ of filter-sterilized L- $\left[{ }^{14} \mathrm{C}\right]$ aspartate (The Radiochemical Center, Amersham, Buckinghamshire, England). $\mathrm{CO}_{2}$ liberated during growth was trapped in $40 \%$ $\mathrm{KOH}$. The specific activities (expressed as counts per minute per microgram of rRNA) of $\left[{ }^{14} \mathrm{C}\right] \mathrm{rRNA}$ of $G$. oxydans subsp. oxydans NCIB 9013, A. aceti subsp. aceti NCIB $8621 \mathrm{t}_{1}$, and $Z$. mobilis subsp. mobilis ATCC 29191 were 4,250, 6,500, and 345, respectively.

Saturation hybridization between $\left[{ }^{14} \mathrm{C}\right] \mathrm{rRNA}$ and filter-fixed DNA. Thermal stability of the DNA:rRNA hybrids. For hybridizations with $\left[{ }^{14} \mathrm{C}\right]-$ rRNA from Gluconobacter and Acetobacter, we followed the methods as described in previous papers from this department $(13,16,17,19)$. In view of the very low specific activity of $Z$ ymomonas $\left[{ }^{14} \mathrm{C}\right] \mathrm{rRNA}$, some modifications were required in the hybridization technique: two filters, each with approximately $80 \mu \mathrm{g}$ of DNA, were hybridized separately with $20 \mu \mathrm{g}$ of $\left[{ }^{14} \mathrm{C}\right]-\mathrm{rRNA}$. The thermal stability of the hybrids was determined by counting for 100 min the amount of labeled material released from both filters together, in $2 \mathrm{ml}$ of $1.5 \times \mathrm{SSC}$ in $20 \%$ formamide, in $10^{\circ}$ steps from 50 to $90^{\circ} \mathrm{C}$. SSC buffer contains $0.15 \mathrm{M} \mathrm{NaCl}$ and 0.015 $\mathrm{M}$ sodium citrate, $\mathrm{pH}$ 7. All labeled material was counted in a Beckman liquid scintillation spectrometer LS $100^{\circ} \mathrm{C}$ at room temperature. $T_{m(e)}$ is the temperature at which $50 \%$ of the hybrid was eluted. The total amount of $\left[{ }^{14} \mathrm{C}\right] \mathrm{rRNA}$ bound, after RNase treatment, expressed in micrograms of rRNA per $100 \mu \mathrm{g}$ of DNA retained on the filter, was called "the percentage of rRNA binding."

Chemical determination of DNA on the filter. For determining the amount of DNA on the filter, we used a previously described method (19).

Determination of the $G+C$ content of the DNA. Several of the moles percent guanine plus cytosine $(\mathrm{G}+\mathrm{C})$ in Tables 1 and 2 were previously published $(16,19,38)$; the other $\mathrm{G}+\mathrm{C}$ values were determined by the thermal denaturation method (18).

\section{RESULTS}

$16 \mathrm{~S}$ and $23 \mathrm{~S}$ fractions. The distribution of the rRNA fractions in sucrose gradients is shown in Fig. 1. No 23S rRNA peak was detectable from $G$. oxydans subsp. oxydans NCIB 9013, and there was but a small peak in the rRNA preparation from $A$. aceti subsp. aceti NCIB $8621 t_{1}$. The 16S rRNA peaks are quite distinct in both cases. This distribution is quite different from that obtained with Escherichia coli (19), where approximately equal $16 \mathrm{~S}$ and $23 \mathrm{~S}$ peaks indicate approximately equal yields of each fraction. The low ratio of $23 \mathrm{~S}$ to $16 \mathrm{~S}$ with NCIB $8621 t_{1}$ is approximately the same as in Agrobac. terium (19). In the latter genus, nicking of the $23 \mathrm{~S}$ rRNA $(24,35)$ explains its low yield; we assume that nicking explains the absence of $23 \mathrm{~S}$ in Gluconobacter and its low yield in Acetobac. ter reference strains. Although the $16 \mathrm{~S}$ peaks are probably heavily contaminated with fragmented $23 \mathrm{~S}$ fractions as in Agrobacterium $(19,35)$, we shall continue to use both symbols for the sake 


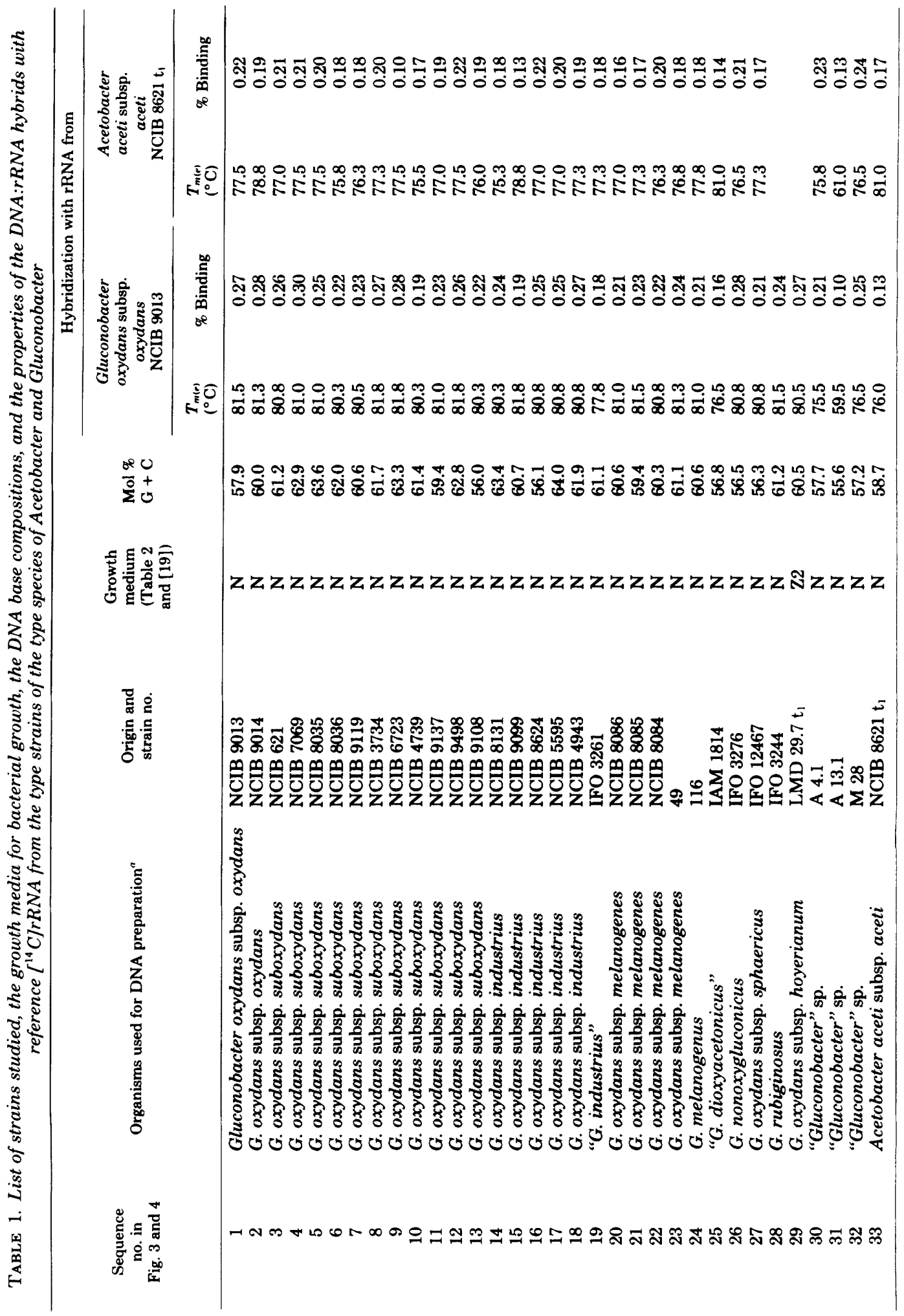




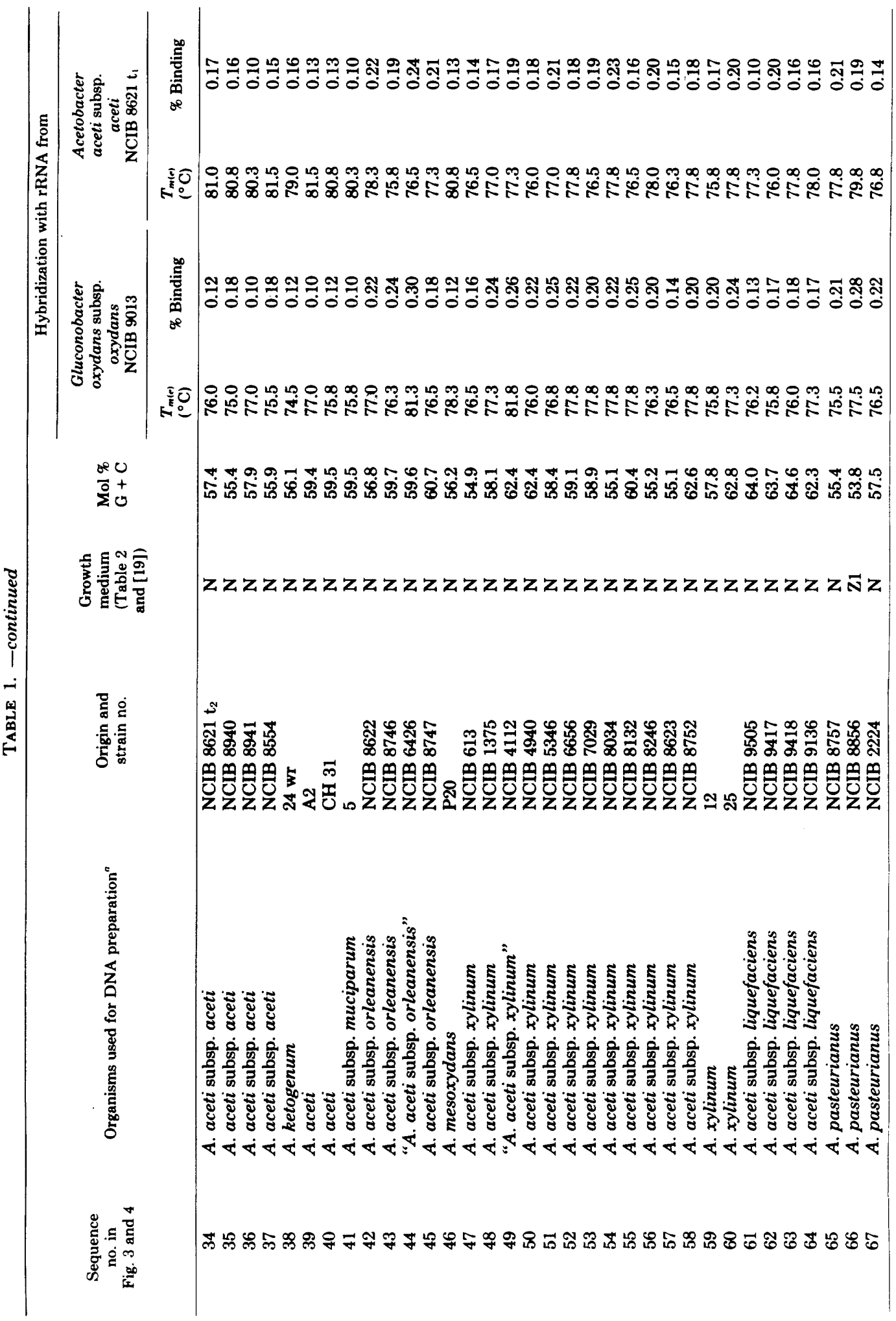




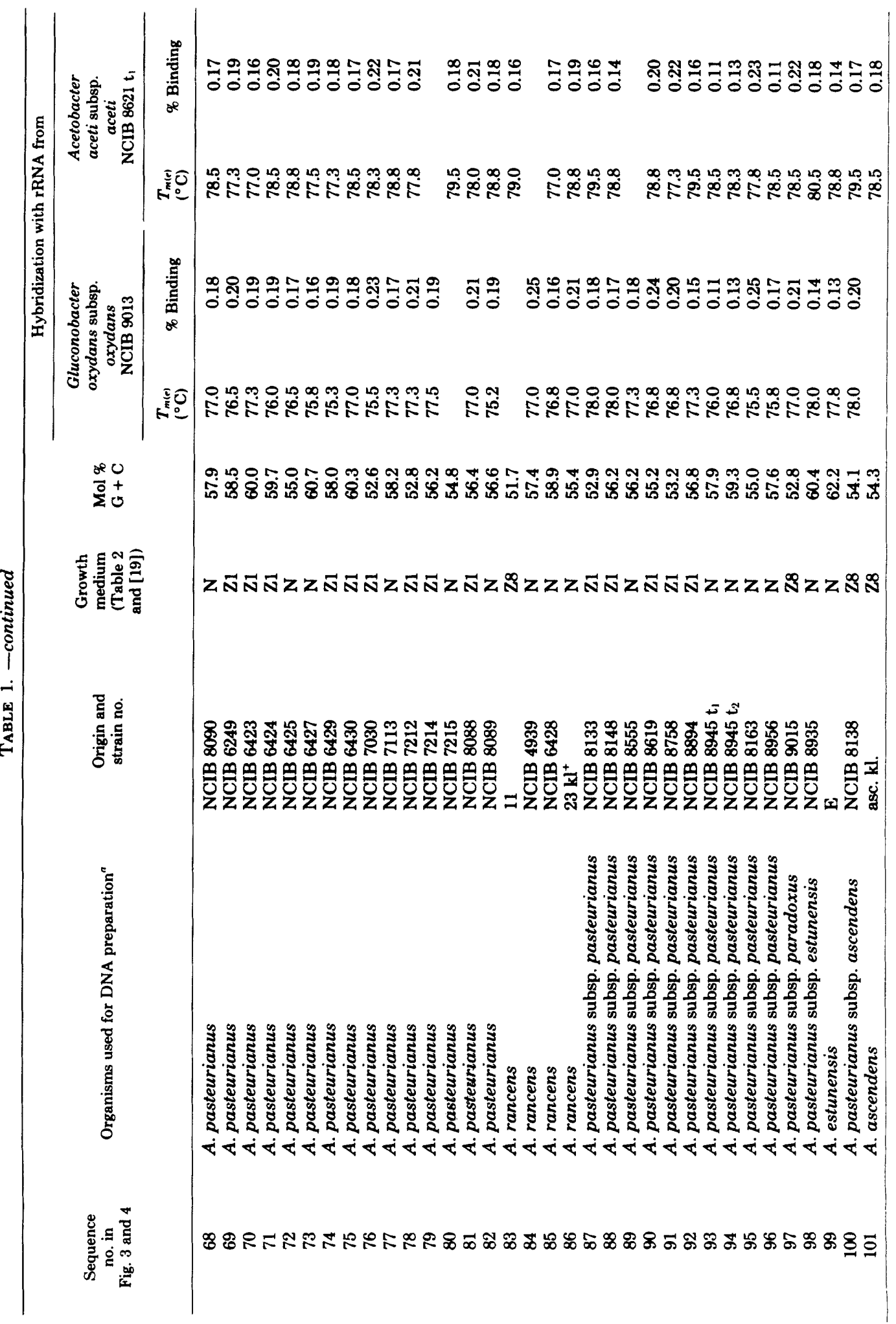




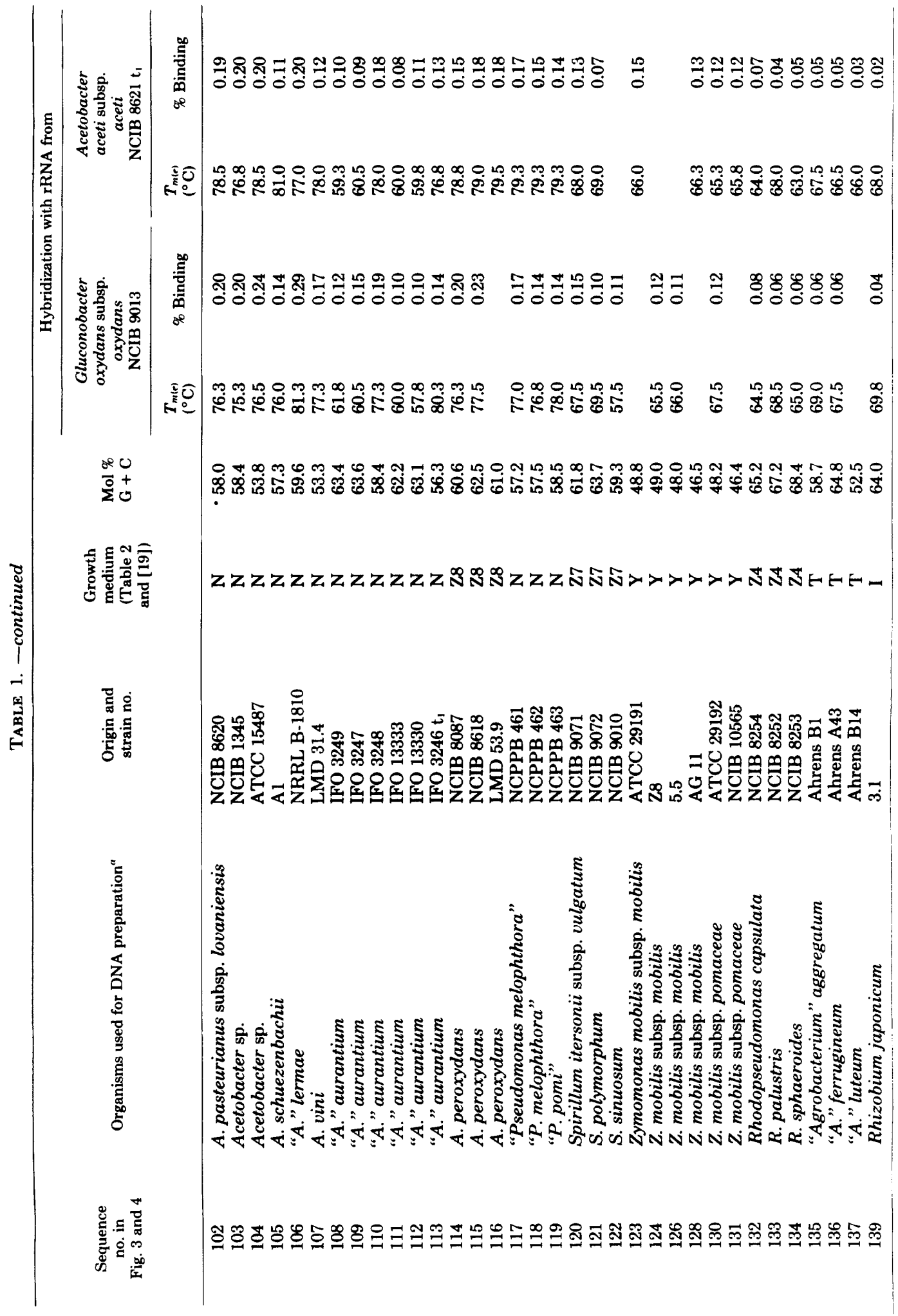




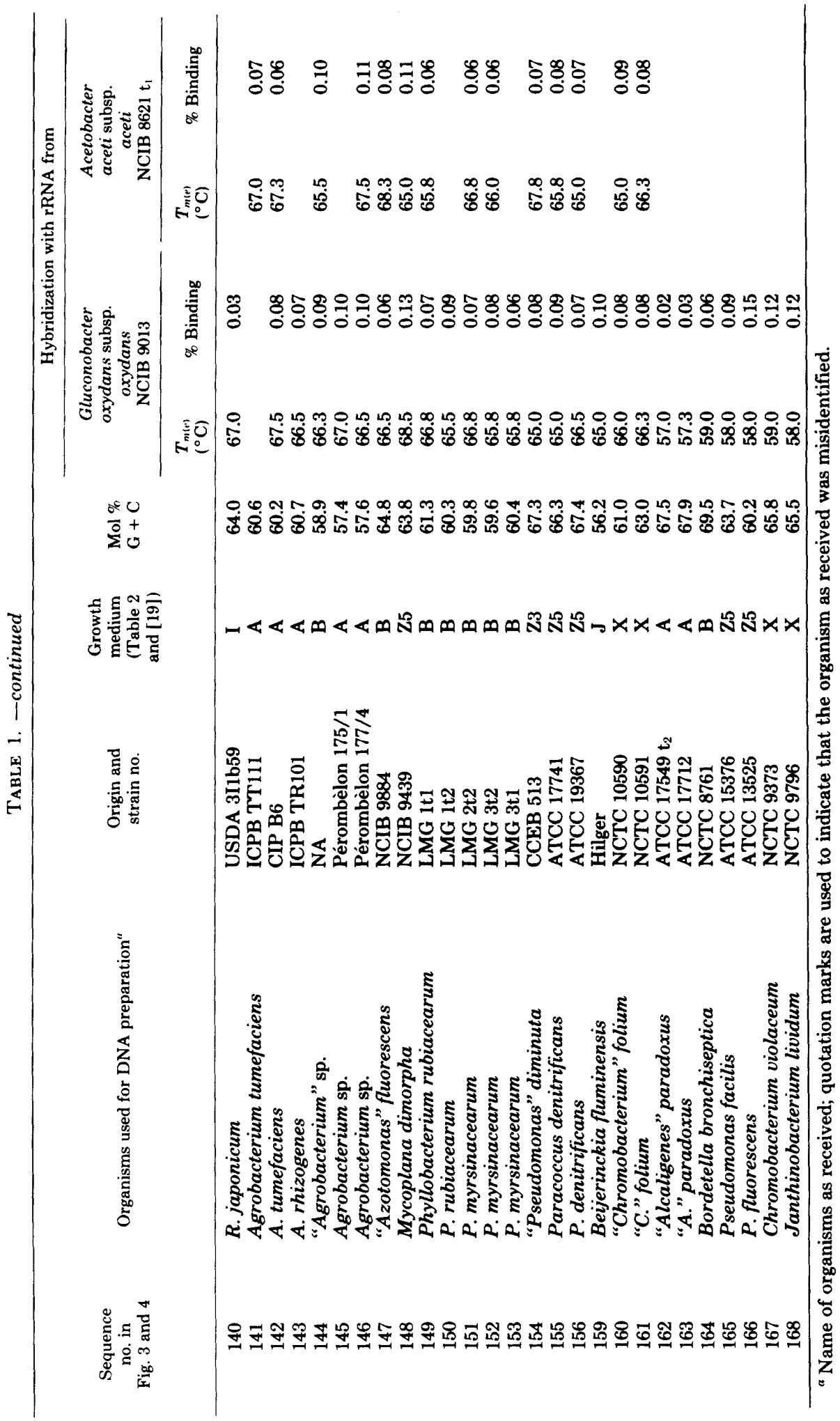




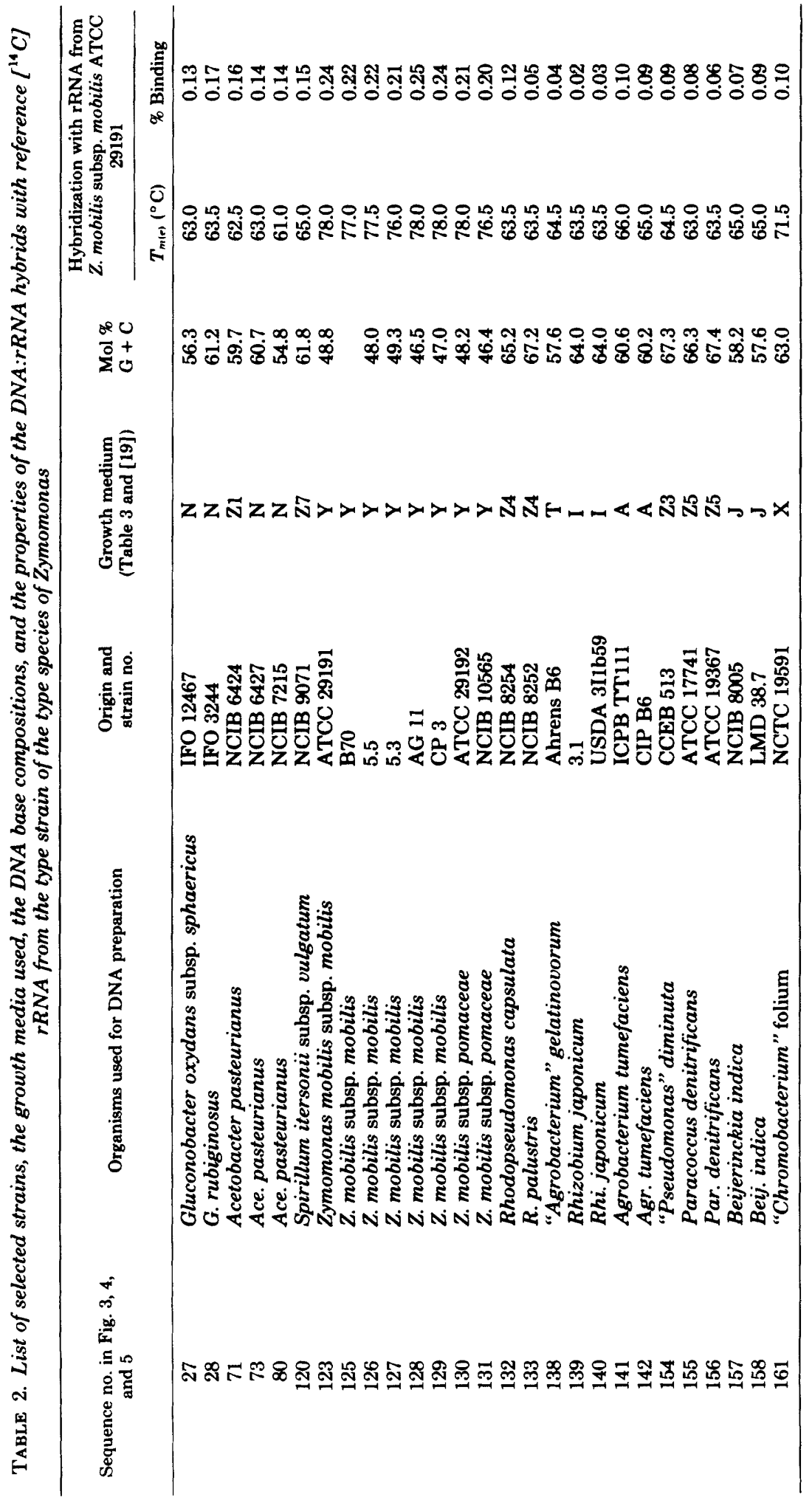


TABLE 3. Compositions of growth media ${ }^{a}$

\begin{tabular}{|c|c|c|c|c|c|c|c|c|}
\hline \multirow{2}{*}{ Ingredient } & \multicolumn{8}{|c|}{ Medium } \\
\hline & $\mathrm{Z1}$ & $\mathrm{Z2}$ & $\mathbf{Z 3}$ & $\mathrm{Z4}$ & $\mathbf{Z 5}$ & Z6 & $\mathbf{Z 7}$ & 28 \\
\hline Glucose & & & $1^{b}$ & & & & & \\
\hline Mannitol & & 2.5 & & & & & & \\
\hline Yeast extract (Oxoid) & 2 & 0.5 & 0.5 & 1 & 0.2 & 0.2 & & 2 \\
\hline Meat extract (Oxoid) & & & & & 0.1 & 0.1 & & \\
\hline Peptone (Oxoid) & & 0.3 & & & 0.5 & 0.5 & 1 & \\
\hline Proteose peptone (Oxoid) & & & 0.5 & & & & & \\
\hline$\left(\mathrm{NH}_{4}\right)_{2} \mathrm{SO}_{4}$ & & & & & & & 0.1 & \\
\hline $\mathrm{K}_{2} \mathrm{HPO}_{4}$ & & & & 0.1 & & & & \\
\hline $\mathrm{NaCl}$ & & & & & 0.5 & 3.5 & & \\
\hline $\mathrm{FeCl}_{3} \cdot 6 \mathrm{H}_{2} \mathrm{O}$ & & & & & & & 0.0002 & \\
\hline $\mathrm{MnSO}_{4} \cdot \mathrm{H}_{2} \mathrm{O}$ & & & & & & & 0.0002 & \\
\hline $\mathrm{MgSO}_{4} \cdot 7 \mathrm{H}_{2} \mathrm{O}$ & & & & 0.05 & & & 0.1 & \\
\hline $\mathrm{CaCO}_{3}$ & & & & & & & & 2 \\
\hline Ca-lactate & 2 & & & & & & & 1 \\
\hline Succinic acid & & & & & & & 0.1 & \\
\hline Red wine (in \% vol/vol) & & & & & & & & 50 \\
\hline Tap water & + & & & + & & & & \\
\hline Distilled water & & + & + & & + & + & + & \\
\hline $\mathrm{pH}$ adjusted to & & & $6.5-7$ & $7-7.2$ & 7.4 & & 6.8 & \\
\hline
\end{tabular}

${ }^{a}$ The compositions of media A, B, N, T, V, X, and Y have been given previously $(16,19)$.

${ }^{b}$ Figures are percentages (wt/vol) unless stated otherwise. Symbol: + , Indicates the kind of water used.
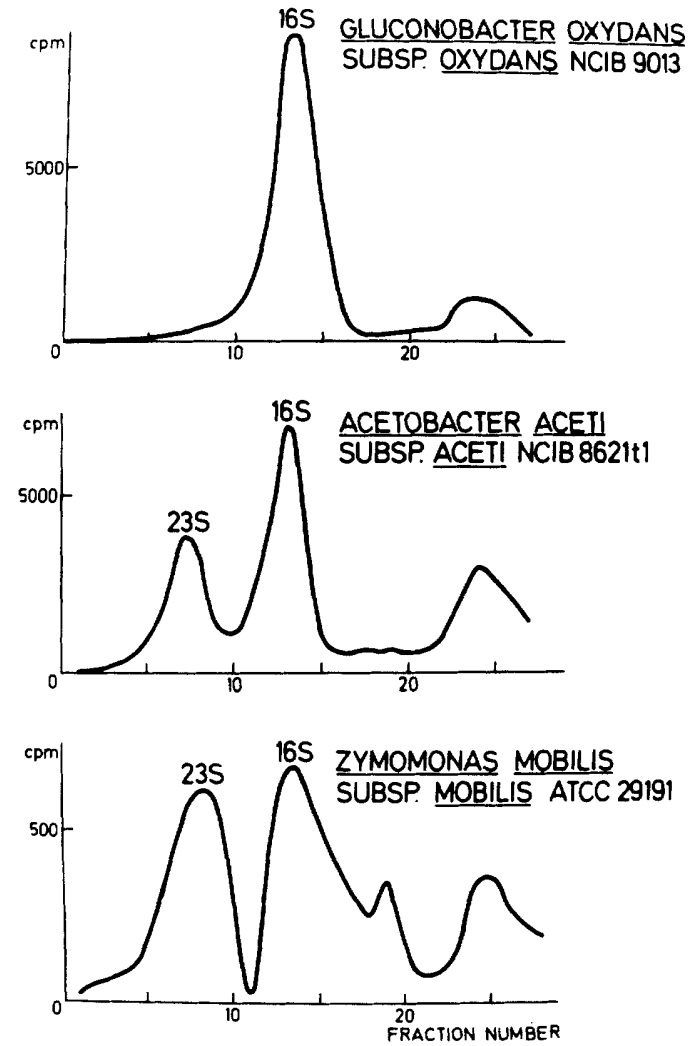

Fig. 1. $\left[{ }^{14} \mathrm{C}\right] \mathrm{rRNA}$ distributions in a linear 15 to $30 \%$ sucrose gradient. of simplicity. There is no evidence that the 23S fraction would be contaminated by the $16 \mathrm{~S}$ fraction. From Z. mobilis subsp. mobilis ATCC 29191, we isolated almost equal amounts of $23 \mathrm{~S}$ and $16 \mathrm{~S}\left[{ }^{14} \mathrm{C}\right] \mathrm{rRNA}$. Although about $50 \%$ of the added $\mathrm{L}-\left[{ }^{14} \mathrm{C}\right]$ aspartate had been consumed by the zymomonad, only $5 \%$ of this amount was assimilated in the bulk rRNA fraction. Other labeled rRNA precursors such as $\left[2{ }^{14} \mathrm{C}\right]$ uracil and $\left[6-{ }^{14} \mathrm{C}\right]$ orotic acid were not taken up at all by zymomonads in medium Y (19). Hybridizations were carried out with 16S rRNA from $G$. oxydans subsp. oxydans NCIB 9013 and with either $23 \mathrm{~S}$ or $16 \mathrm{~S}$ from $A$. aceti subsp. aceti NCIB $8621 \mathrm{t}_{1}$ and from $Z$. mobilis subsp. mobilis ATCC 29191. Homologous and heterologous hybridizations with 23S and 16S rRNA from $A$. aceti subsp. aceti (Table 4) and from Zymomonas gave similar results within the limits of reproducibility of $\pm 0.5^{\circ} \mathrm{C}$ for $T_{m(e)}$ and $\pm 0.015 \%$ for the percentage of rRNA binding (19).

Comparison of DNA:rRNA hybrids. The DNA:rRNA hybridization data are compiled in Tables 1 and 2. They will be evaluated extensively in the Discussion. $T_{m(e)}$ and percentage of rRNA binding were obtained from the melting curves of the hybrids. A few examples are given in Fig. 2. For each labeled reference rRNA, $T_{m(e)}$ was plotted versus the percentage of rRNA binding for each DNA:rRNA hybrid resulting in rRNA similarity maps (Fig. 3 through 5 ). $T_{m(e)}$ is the most useful of both parameters $(16,19)$. It 
TABLE 4. $T_{m(e)}$ and the percent $r R N A$ binding of hybrids formed between either 16S or 23S rRNA from A. aceti subsp. aceti NCIB $8621 t_{1}$ and DNA from several other acetic acid bacteria

\begin{tabular}{|c|c|c|c|c|}
\hline \multirow{3}{*}{ Organism used for DNA preparation } & \multicolumn{4}{|c|}{ rRNA from A. aceti subsp. aceti NCIB $8621 \mathrm{t}_{1}$} \\
\hline & \multicolumn{2}{|c|}{$16 S$} & \multicolumn{2}{|c|}{$23 \mathrm{~S}$} \\
\hline & $\begin{array}{l}T_{\text {nule }} \\
\left({ }^{\circ} \mathrm{C}\right)\end{array}$ & \% Binding & $\begin{array}{l}T_{m(l)} \\
\left({ }^{\circ} \mathrm{C}\right)\end{array}$ & \% Binding \\
\hline A. aceti subsp. aceti $\mathrm{NCIB} 8621 \mathrm{t}_{1}$ & 80.8 & 0.16 & 81.0 & 0.19 \\
\hline A. aceti $\mathrm{A}_{2}$ & 81.8 & 0.11 & 81.5 & 0.14 \\
\hline A. aceti subsp. liquefaciens NCIB 9136 & 77.8 & 0.14 & 78.0 & 0.17 \\
\hline A. aceti subsp. aceti NCIB 8940 & 80.8 & 0.17 & 81.0 & 0.17 \\
\hline G. oxydans subsp. oxydans NCIB 9013 & 77.3 & 0.20 & 77.5 & 0.24 \\
\hline
\end{tabular}

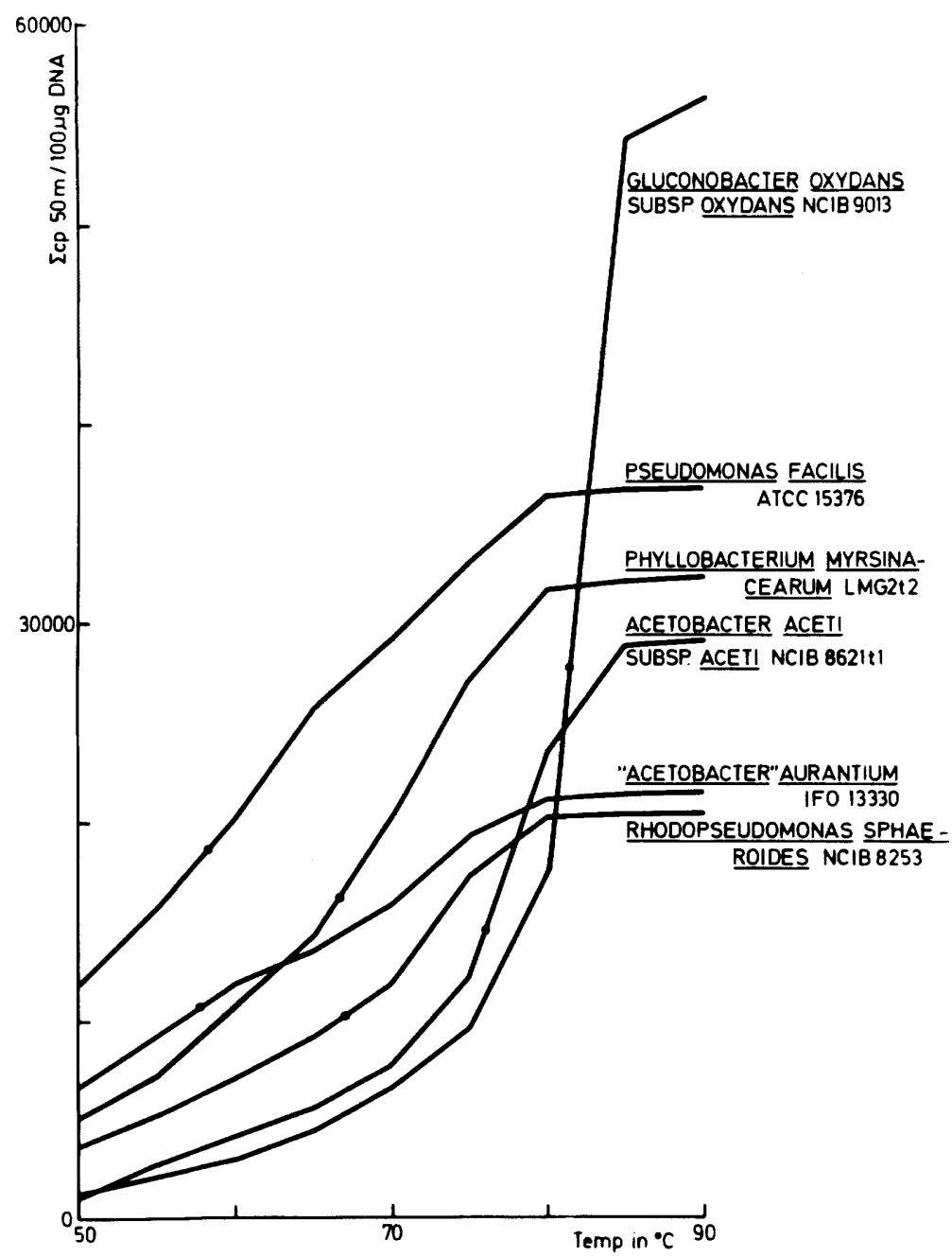

FIG. 2. Examples of melting curves of hybrids between $16 S\left[{ }^{14} \mathrm{C}\right] \mathrm{rRNA}$ from G. oxydans subsp. oxydans NCIB 9013 and filter-fixed DNA from various bacteria. The total amount of cp50m per $100 \mu \mathrm{g}$ of DNA (counts per $50 \mathrm{~min}$ per $100 \mu \mathrm{g}$ of filter-fixed DNA) is a measure of the amount of hybrid denatured. The melting point, $T_{m(e)}$, is identified by the dot on each curve. 
has to be stressed that the percentage of rRNA binding is not a measure of rRNA cistron homology because it depends not only on the actual rRNA homology but also on the number of rRNA cistrons per genome, the size of the genome, and its state of replication; practice has shown that it is a useful parameter only in separating taxa $(16,19)$. Data on reciprocal hybridizations between DNA from Acetobacter, Gluconobacter, and Zymomonas and $\left[{ }^{14} \mathrm{C}\right] \mathrm{rRNA}$ from other genera are summarized in Table 5; they are in excellent agreement with the hybridizations reported in Tables 1 and 2 and strengthen our discussion given below.

\section{DISCUSSION}

rRNA similarities (Fig. 3 to 5 ). The $T_{m(e)}$ similarity between RNA cistrons from different bacteria is a measure of their relationship at the inter- and suprageneric level and can be used for taxonomic and identification purposes.' The basic aspects of the discussion on the rRNA similarity maps were given earlier $(16,19)$. Each strain has a fixed position on each map within the limits of reproducibility. Each taxon occupies a definite area on a rRNA similarity map $(13,16,19)$. When many strains are included, the size and shape of the rRNA similarity area provide a rough measure of the internal phenotypic and genetic heterogeneity of the taxon. A few strains suffice to localize a genus on the map.

The genus Gluconobacter. According to Bergey's Manual, eighth edition (8), the genus Gluconobacter consists of one species, $G$. oxydans, and four subspecies, $G$. oxydans subsp. oxydans, G. oxydans subsp. industrius, G. oxydans subsp. suboxydans, and G. oxydans subsp. melanogenes. Representative strains of each of these subspecies were included as well as variously named strains from several collections. We included a total of 27 authentic Gluconobacter strains (Fig. 3 and 4 and Table 1). When their DNAs were hybridized with $\left[{ }^{14} \mathrm{C}\right] \mathrm{rRNA}$ of the type strain of $G$. oxydans subsp. oxydans NCIB 9013 , they all fell into a well-defined area with $T_{m(e)}$ from 80.3 to $81.8^{\circ} \mathrm{C}$ and 0.18 to $0.30 \%$ rRNA binding. When their DNA was hybridized with $\left.{ }^{14} \mathrm{C}\right] \mathrm{rRNA}$ from $A$. aceti subsp. aceti NCIB $8621 t_{1}$, they fell into an area between $T_{m(e)} 75.3$ and $78.8^{\circ} \mathrm{C}$ and between 0.13 and $0.22 \%$ rRNA binding. The area delineated by hybridization with NCIB $9013\left[{ }^{14} \mathrm{C}\right] \mathrm{rRNA}$ was clearly separated from all other genera. Into that area fell, in addition to the named Gluconobacter strains, a number of differently named strains $(A$. aceti subsp. xylinum NCIB 4112, $A$. aceti subsp. orleanensis NCIB 6426, A. lermae NRRL B-1810, and $A$. aurantius IFO $\left.3246 \mathrm{t}_{1}\right)$. On the basis of our previous experience $(16,19)$ that the position of a strain in the rRNA similarity maps and in particular the value of $T_{m(e)}$ are powerful aids for identification, we concluded that the latter four strains were misnamed and belong in Gluconobacter. There is additional evidence supporting this conclusion.

"A." lermae NRRL B-1810, isolated from fermenting agave juice near lake Lerma in Mexico in 1950 (23), is phenotypically a typical Gluconobacter (J. De Ley, K. Kersters, and J. Swings, manuscript in preparation). Its exact taxonomic position in this genus is being worked out.

A. aceti subsp. orleanensis NCIB 6426, isolated from a ropy sample of top-fermented beer in the United Kingdom, was originally named $A$. viscosum (42). It was found in our department to be phenotypically a gluconobacter; its protein electrophoretogram located it in $G$. oxydans subsp. suboxydans (K. Kersters and J. De Ley, manuscript in preparation).

The third strain, NCIB 4112, is an interesting taxonomic case. We received it from the NCIB as Acetobacter aceti subsp. xylinum. According to the NCIB catalogue, this strain is the original "la bactérie du sorbose" of Bertrand $(6,7,21)$. However, this strain is located in the Gluconobacter area of the rRNA similarity map (Fig. 3). Phenotypically, it does not overoxidize acetic acid; it does not form a thick leathery pellicle; it effects no or very weak ketogenesis from mannitol, sorbitol, and glycerol (the very active ketogenesis of the authentic "bactérie du sorbose" was the origin of the discovery of this phenomenon); and in colony morphology and other cultural aspects, this strain is quite different from well-known $A$. aceti subsp. xylinum strains. Its protein electrophoregram is very close to those of authentic $G$. oxydans subsp. suboxydans strains (J. De Ley, K. Kersters, and J. Swings, manuscript in preparation). Acetobacter $x y$. linum CIP 57.14, from the Collection de l'Institut Pasteur, has exactly the same protein electrophoretogram as NCIB 4112 . We concluded that NCIB 4112 and CIP 57.14 are members of $G$. oxydans subsp. suboxydans and not Bertrand's sorbose bacterium. The results of an attempt to identify Bertrand's sorbose bacterium will be described elsewhere.

The following strains fall outside the Gluconobacter area in the rRNA similarity map: "Gluconobacter" industrius IFO 3261, "Gluconobacter" dioxyacetonicus IAM 1814, and "Gluconobacter" strains A4.1 and M28. We conclude that these strains are misnamed and do not belong in Gluconobacter. They will be discussed below with Acetobacter. "Gluconobacter" strain 13.1 was presumably isolated from ripening honey 


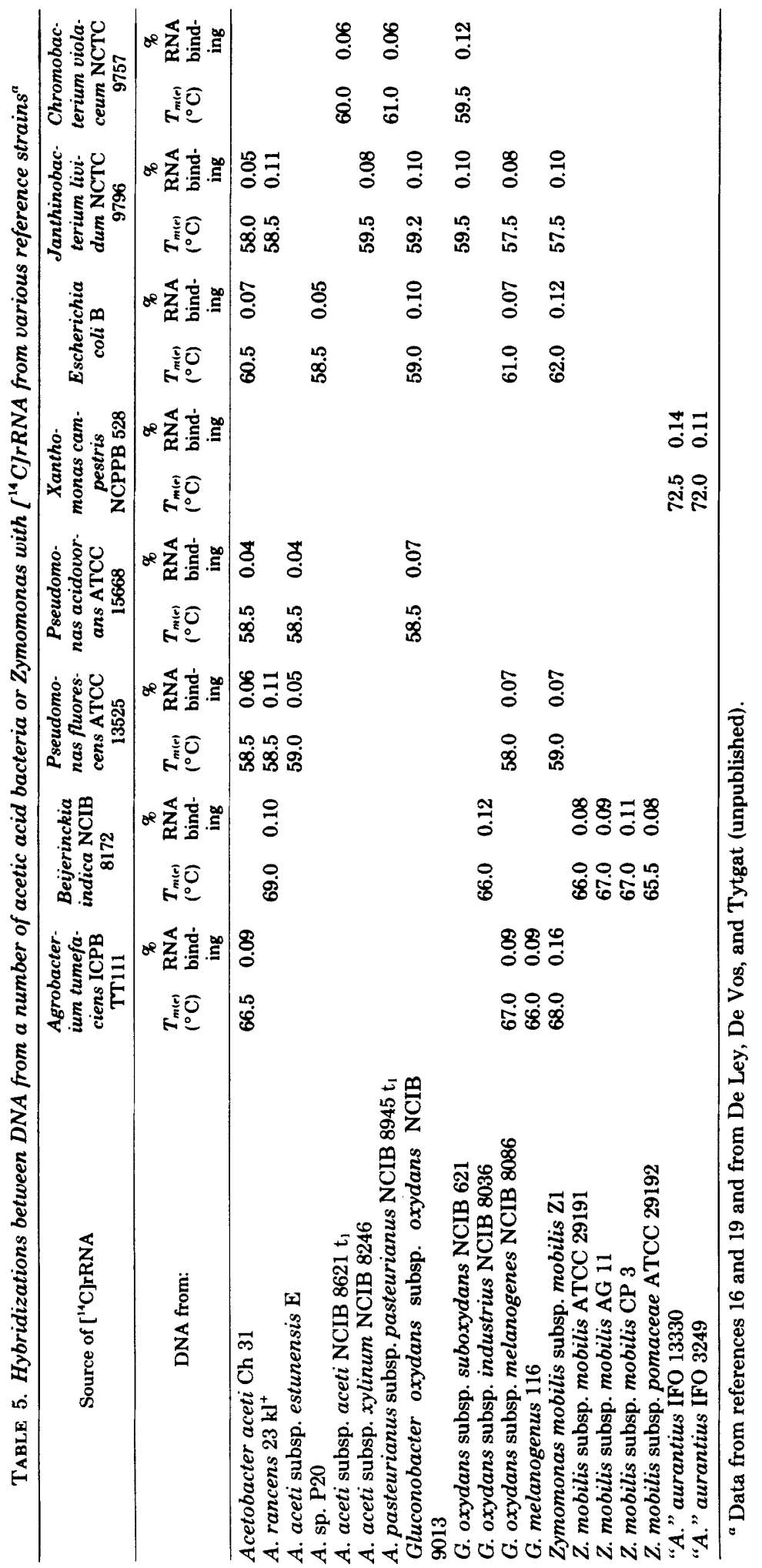




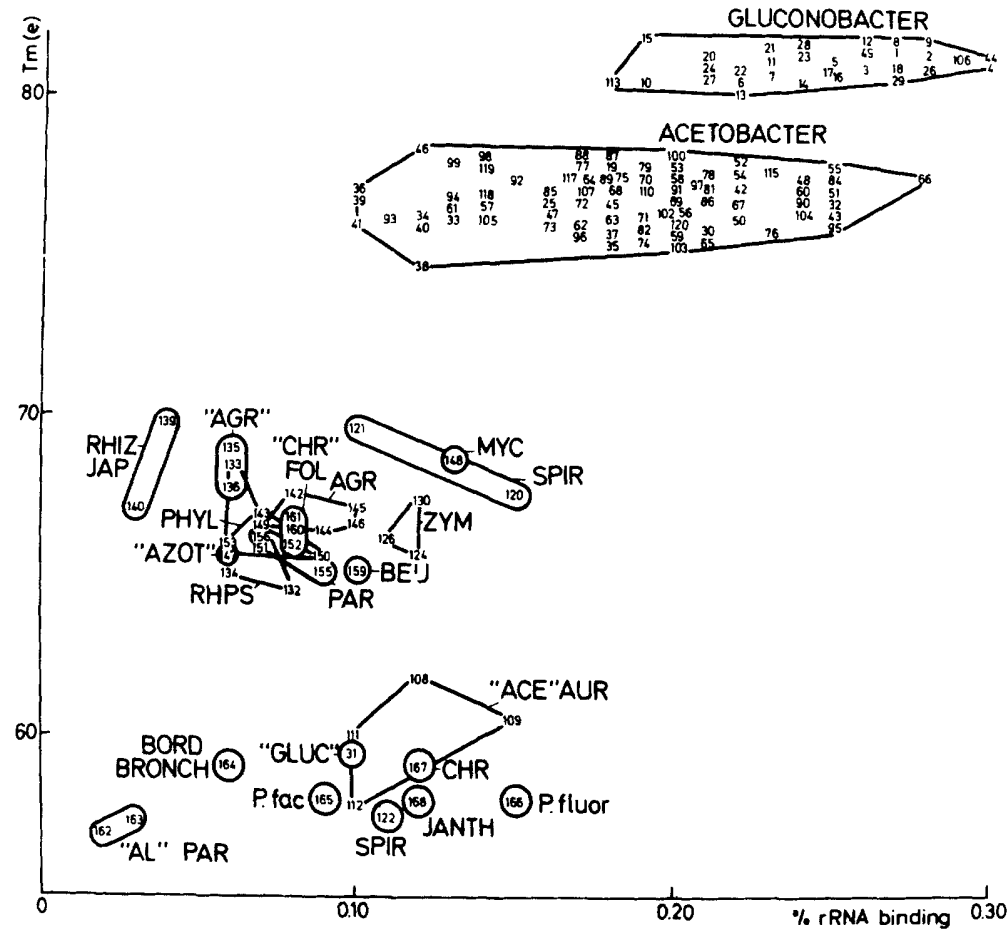

FIG. 3. Similarity map of hybrids between the $16 S\left[{ }^{14} C\right] r R N A$ fraction of G. oxydans subsp. oxydans NCIB 9013 and DNA from a variety of bacteria. $T_{m(e)}$ and percent $r R N A$ binding are as defined in the text. To simplify the drawing, each strain is represented by a sequence number (Table 1 and 2) which is not the strain number. The positions of all strains belonging phenotypically to the same taxon (usually a genus) are indicated by a closed line. These areas locate the taxa on the map. It is our experience that taxa which do not belong in an rRNA superfamily always have the same location on the similarity map no matter which ${ }^{14} \mathrm{C}$ reference rRNA from the rRNA superfamily is used. Therefore, we used but a limited number of strains from these taxa (Pseudomonas, Chromobacterium, Escherichia, etc.) (16, 19, the present paper, and many data to be published from this laboratory). Abbreviations: Ace, Acetobacter; "Ace" aur, "Acetobacter" aurantius; Agr, Agrobacterium; "Agr," "Agrobacterium"; "Al" par, "Alcaligenes" paradoxus; "Azot," "Azotomonas" fluorescens; Beij, Beijerinckia; Bord bronch, Bordetella bronchiseptica; Chr, Chromobacterium violaceum; "Chr" fol, "Chromobacterium" folium; Gluc, Gluconobacter; "Gluc," "Gluconobacter" sp.; Janth, Janthinobacterium lividum; Myc, Mycoplana dimorpha; $P$. fac, Pseudomonas facilis; P. fluor, Pseudomonas fluorescens; Par, Paracoccus denitrificans; Phyl, Phyllobacterium; Rhiz jap, Rhizobium japonicum; Rhps, Rhodo. pseudomonas; Spir, Spirillum; and Zym, Zymomonas.

and honey bees $(32,34)$. With a $T_{m(e)}$ of $61^{\circ} \mathrm{C}$, this strain definitely does not belong with the acetic acid bacteria (Fig. 4). It is a fast-growing organism which produces copious amounts of polysaccharide and forms yellow, slimy colonies, characteristics which are in contradiction with the original description $(33,34)$ and with the characteristics (14) of acetic acid bacteria. The exact taxonomic position of this organism remains to be resolved.

The genus Acetobacter. According to Bergey's Manual, eighth edition, (8), Acetobacter consists of three species: $A$. aceti, A. pasteurianus, and $A$. peroxydans. The first of these was divided into four subspecies ( $A$. aceti subsp. aceti, $A$. aceti subsp. orleanensis, $A$. aceti subsp. xylinum, and $A$. aceti subsp. liquefaciens); and the second, into five subspecies (A. pasteurianus subsp. pasteurianus, A. pasteurianus subsp. lovaniensis, $A$. pasteurianus subsp. estunensis, $A$. pasteurianus subsp. ascendens, and $A$. pasteurianus subsp. paradoxus). Representative strains of all of these taxa as well as variously named strains from several collections, a total of 78 authentic Acetobacter strains (Table 1, Fig. 3 and 4), were included in this study. When their DNAs were hybridized with $\left[{ }^{14} \mathrm{C}\right] \mathrm{rRNA}$ of $A$ ce tobacter aceti subsp. aceti NCIB $8621 \mathrm{t}_{1}$, they fell into a cluster with $T_{m(e)}$ 's from 75.7 to $81.5^{\circ} \mathrm{C}$ and with 0.10 to $0.24 \%$ rRNA binding. The Acetobacter and Gluconobacter areas overlap (see below). When Acetobacter DNA was hybridized 


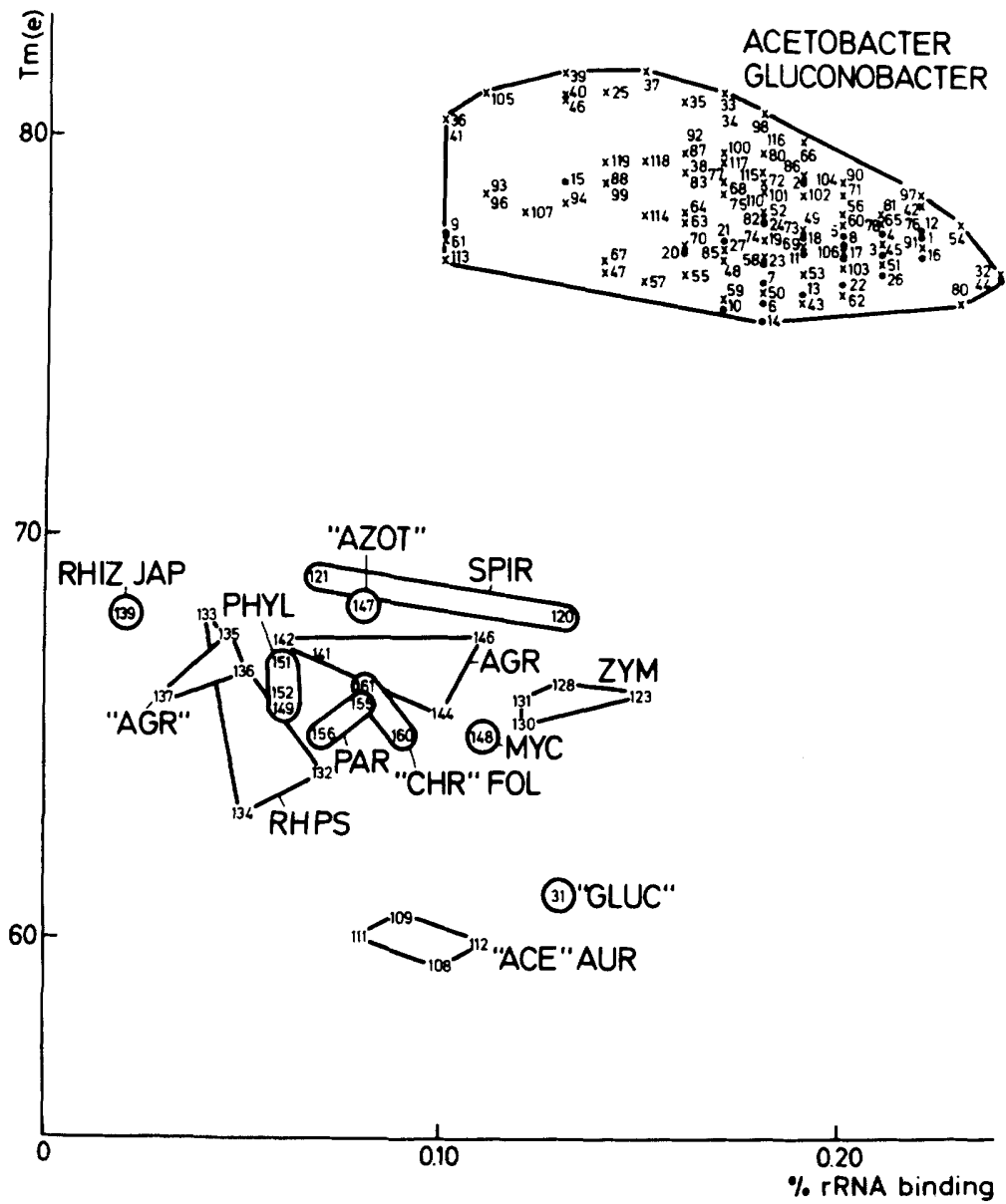

FIG. 4. Similarity map of hybrids between the $16 S\left[{ }^{14} C\right] r R N A$ fraction of $A$. aceti subsp. aceti NCIB 8621 $t_{1}$ and DNA from a variety of bacteria. For further details, see legend to Fig. $3 . \times$, Acetobacter; Gluconobacter.

with $\left[{ }^{14} \mathrm{C}\right] \mathrm{rRNA}$ from Gluconobacter NCIB 9013, the Acetobacter area extended from $T_{m(e)}$ 74.5 to $78.3^{\circ} \mathrm{C}$ and from 0.10 to $0.28 \%$ rRNA binding.

$A$. peroxydans is an unusual acetic acid bacterium. It occurs in ditch water or household sewage as lightly tapered rods in pairs. By contrast to the other acetobacters, this species is unable to grow on and to produce acid from carbohydrates; it is not ketogenic and has no catalase. It appears to live mainly on ethanol or lactate or both $(10,22)$. Some strains have been reported to oxidize hydrogen $(10,41)$. Although this species overoxidizes ethanol and grows at a low $\mathrm{pH}$ of 4.5 , it is quite different from authentic acetobacters, and there is no completely convincing proof that it really belongs in Acetobacter. The same is true of $A$. paradoxus, an organism that grows very poorly, has no catalase, lives mainly on ethanol or lactate, and displays only a few of the features characteristic of acetic acid bacteria (22). The data presented here on the taxonomic position of these species are the first convincing arguments that both species really belong in Acetobacter.

Quasi-Acetobacter and quasi-Acetomonas. The former term has been used to denote acetic acid bacteria mutants which have lost the power of acetifying ethanol (37). The taxonomic position of these organisms remained vague, particularly since Shimwell (37) repeatedly stressed that the loss of this one feature (ability to oxidize ethanol to acetic acid) catapulted these organisms clear out of their original genus. However, a genus is a group of organisms characterized by a set of correlated phenotypic features and by distinct genetic similarity. Mutative loss in a strain of one or a few of the phenotypic features from this set does not change its genetic and taxonomic position. We 


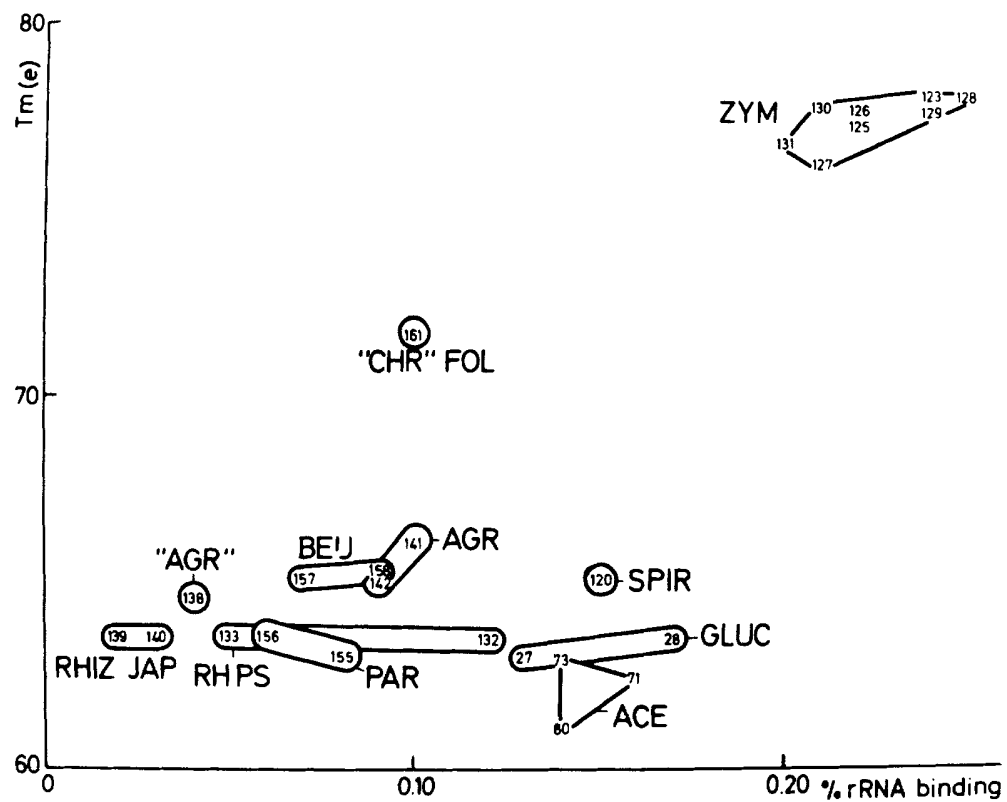

Fig. 5. Similarity map of hybrids between the $16 \mathrm{~S}$ and $23 S\left[{ }^{14} \mathrm{CJ}\right.$ RNA fractions of Zymomonas mobilis subsp. mobilis ATCC 29191 and DNA from a variety of bacteria. For further details, see legend to Fig. 3.

examined one "quasi-acetobacter"-NCIB 8956 (received as $A$. pasteurianus subsp. pasteurianus). It fell within the Acetobacter area, and there is thus no reason to remove it from that genus. We also examined $G$. oxydans subsp. suboxydans NCIB 9498, which was originally received by the NCIB as a "quasi-acetomonas." It fell within the Gluconobacter area. The concept of "quasi-acetobacter" and "quasi-acetomonas" is taxonomically not justified and is redundant.

Into the Acetobacter area (Fig. 3) fell a few organisms which had been placed in genera other than Acetobacter. We submit that they have been misnamed, and we will present here phenotypic evidence to support this claim.

"Gluconobacter industrius" IFO 3261 (= Kondô 42). This organism falls into the Acetobacter cluster (Fig. 3). Phenotypic data which confirm our conclusion that this organism is an acetobacter and not a gluconobacter are (i) its oxidation of acetate (observed by Ameyama et al. [2] and in our laboratory) and (ii) its protein electrophoretogram differs from that of any known gluconobacter (K. Kersters and J. De Ley, manuscript in preparation).

"Gluconobacter dioxyacetonicus" IAM 1814 (= Asai A15). The following phenotypic data derived from this strain confirm our conclusion that it is an acetobacter: (i) the nature of the ubiquinone present (43), (ii) the presence of the Krebs cycle (27), (iii) acid formation from ethanol, overoxidation of ethanol, and growth on lactate, and (iv) the protein electrophoretogram (J. De Ley, K. Kersters, and J. Swings, manuscript in preparation).

"Gluconobacter" sp. strains A4.1 and M28. A few years ago Ruiz-Argüieso and Rodriguez-Navarro $(33,34)$ isolated gluconic acid-producing bacteria from ripening honey and honey bees in the Madrid area. They seemed to fit best in Gluconobacter. Rodriguez-Navarro kindly sent us the strains labeled Gluconobacter A4.1 and M28. Their protein electrophoretograms do not correspond to those of any of numerous authentic Gluconobacter strains examined from all over the world. The phenotypic features of strain A4.1 indicate that it is an unusual acetic acid bacterium (K. Kersters, J. Swings, and J. De Ley, manuscript in preparation). On the basis of DNA:rRNA hybridization, both strains fall into the Acetobacter, not the Gluconobacter, area (Fig. 3). The taxonomic positions of these organisms are being investigated.

"Pseudomonas" melophthora NCPPB 461 (= Cole 2A) and 462 (= Cole $4 \mathrm{~A})$. In a separate project in our laboratory, the taxonomic positions of many of the pseudomonads cited in the addenda in Bergey's Manual, eighth edition were investigated by DNA:rRNA hybridization. "P." pomi and " $P$." melophthora did not belong in Pseudomonas (P. De Vos and J. De Ley, manuscript in preparation). The latter is listed in Bergey's Manual, eighth edition (8) as of uncertain position (incertae sedis) in Addendum I to Pseudomonas. Allen and Riker (1) described 
a rot of apple fruit in the United States caused by Phytomonas melophthora sp. nov. after invasion by an apple maggot. Strains of this species are not known to exist. Cole (9) described a bacterial rotting of apple fruit in the United Kingdom. His two pathogenic isolates, $2 \mathrm{~A}$ and $4 \mathrm{~A}$, were considered to be identical with $P$. melophthora. On the rRNA similarity map (Fig. 3), they fell in the Acetobacter area. Phenotypically, both strains belong in Acetobacter (acid from ethanol; overoxidation; growth on acetate, lactate, and glycerate; not ketogenic [J. Swings and J. De Ley, manuscript in preparation]). The protein electrophoretograms show that the two strains are identical and that they are not gluconobacters. We conclude that Cole's (9) strains are misnamed and belong in Acetobacter.

"Pseudomonas" pomi NCPPB 463 (= Cole A1). This strain is the type strain of P. pomi (9). It was isolated from and caused the rotting of apples in the United Kingdom. It was very similar to "P." melophthora, except that it was nonmotile and capsulated. Its rRNA properties located it in the Acetobacter area (Fig. 3). Our conclusion that it is an acetobacter is strengthened by phenotypic characters: it produces acid from ethanol, grows on acetate, lactate, and glycerate, oxidizes acetate and lactate, grows at $\mathrm{pH} 3.55$, and is not ketogenic (J. Swings and J. De Ley, manuscript in preparation). The same three strains were examined by Dhanvantari, et al. (20), who concluded from phenotypic features that they are members of $A$. pasteurianus (Hansen 1879) Beijerinck 1898.

A few strains received under the generic name Acetobacter were misnamed. We have already mentioned three of them (NRRL B-1810, NCIB 6426 , and NCIB 4112) which belong in Gluconobacter. Several "A." aurantius strains (IFO 3247 , IFO 3249 , IFO 13330, and IFO 13333) are not acetic acid bacteria at all and will be discussed below.

The "intermediate" strains. A number of strains of acetic acid bacteria display features of both Acetobacter and Gluconobacter and yet appear not to fit in with either genus. They have been kept as a separate group and have been referred to as "intermediate" strains (5). There are two groups of them, and they will be discussed separately.

The first group consists of four strains originally named Gluconobacter liquefaciens Asai G-1 (= NCIB $9136=$ IAM 1834), G. liquefaciens NCIB 9505, G. melanogenus Asai A-8 (= NCIB $9418=$ IAM 1835), and G. melanogenus Asai U4 (= NCIB 9417 = IAM 1836), all isolated in Japan (sequence numbers 61 to 64 , Table 1). These organisms resemble acetobacters in that they are peritrichous, overoxidize ethanol, and grow at a low $\mathrm{pH}$ (3.5); they resemble gluconobacters because they are ketogenic, have a positive $\mathrm{FeCl}_{3}$-reaction, and produce a brown, water-soluble pigment, as do authentic strains of $G$. melanogenus. These organisms differ from many Acetobacter strains by the production of reducing substances from glucose, gluconate, glycerol, and mannitol and differ from authentic gluconobacters in their growth ratio on lactate and glucose, in the oxidation of lactate and acetate, in the deamination of amino acids, in their requirements for vitamins, and in the type of flagellation. One of us (14) considered that the small differences these strains had from the genus Acetobacter did not preclude these strains from membership in this genus as a separate subspecies-A. aceti subsp. liquefaciens. Our present results support this conclusion: the parameters of the rRNA hybrids of these four strains put these strains directly into the Acetobacter area (Fig. 3). Phenotypically, these strains are typical members of Acetobacter, and their protein electrophoretograms are almost identical (J. De Ley, K. Kersters, and J. Swings, manuscript in preparation). It is our conclusion that these four strains are authentic members of Acetobacter.

The second group consists of several brown pigment-producing strains named $A$. aurantius isolated from Lilium auratum Lindl. $(3,29)$ and from Rubus parvifolius (44). These organisms are similar to acetobacters in that they grow better on lactate than on glucose (with Casamino Acids), oxidize succinate, acetate, and amino acids, and do not require vitamins; on the other hand, they are polarly flagellated and are ketogenic with some sugars, just as are gluconobacters. Most or all of these strains grow at pH 3.5. On the basis of a number of phenotypic features, Ameyama and Kondô (3), Asai (4), and Yamada et al. (44) proposed that the $A$. aurantius strains are acetic acid bacteria which belong to neither Acetobacter nor Gluconobacter but which are intermediate between these genera. We find that the $A$. aurantius strains belong in three taxa: strain IFO 3248 is located in the Acetobacter area, strain IFO 3246 is located in the Gluconobacter area (Fig. 3), and all other "A." aurantius strains that we examined (IFO $3249,3247,13330$, and 13333) are very far removed from the genera Acetobacter and Gluconobacter because they have a $T_{m(e)}$ of about $60^{\circ} \mathrm{C}$. The latter fall completely out of the acetic acid bacteria clusters, and they will be discussed extensively in a separate paper (J. De Ley, J. Swings, K. Kersters, M. Gillis, and P. De Vos, manuscript in preparation). 
Relationships between Acetobacter and Gluconobacter. $T_{m(e)}$ and percentage of rRNA binding of the hybrids show that Acetobacter and Gluconobacter are closely related: when DNA of their strains is hybridized with rRNA from the type strain of the type species of Gluconobacter, G. oxydans NCIB 9013, both genera remain separated (Fig. 3), but they overlap when the same DNAs are hybridized with rRNA from the type strain of the type species of Acetobac.

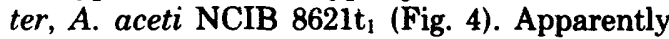
there are many Acetobacter and Gluconobacter strains whose rRNA cistrons are equally different from the reference Acetobacter rRNA. The Gluconobacter area is much smaller than the Acetobacter area, indicating that the former genus is more homogeneous than the latter; this observation agrees very well with the known facts that Acetobacter has a much greater phenotypic variation and a wider range of moles percent $\mathrm{G}+\mathrm{C}$ of the DNA (13).

When the DNA:rRNA hybridization method is to be used for identification purposes, hybridizations with $\left[{ }^{14} \mathrm{C}\right] \mathrm{rRNA}$ from Gluconobacter strain NCIB 9013 in conjunction with Fig. 3 can decide whether an unknown strain belongs in Gluconobacter or in Acetobacter, hybridizations with $\left[{ }^{14} \mathrm{C}\right] \mathrm{rRNA}$ from an Acetobacter reference strain cannot. One of us reported before $(16,19)$ that the DNA:rRNA hybridization method is of little use in distinguishing between species within a genus. This was confirmed in the present paper; strains belonging to different species and subspecies of Acetobacter and to different subspecies of $G$. oxydans are distributed throughout their respective genus areas.

Both genera link at an average $T_{m(e)}$ of 76.8 $\pm 0.9^{\circ} \mathrm{C}$. We examined many other organisms but found no other taxa which are so closely located to either genus. In previous contributions $(16,19)$ we brought evidence that $T_{m(e)}$ is a good measure of relatedness. This is confirmed here: phenotypically, Acetobacter, in particular $A$. aceti, and Gluconobacter are more similar to each other than to any other known genus. The main similarities are (we quote from [12] with the permission of the editor-in-chief, the publisher, and the author): "acid resistance; oxidation by both growing and resting cells of numerous hexoses and pentoses to the corresponding lactones and acids; oxidation of numerous polyols, i.e. glycerol, tetritols, pentitols, hexitols, heptitols, octitols, to ketocompounds according to the Rule of Bertrand-Hudson, unique for acetic acid bacteria, oxidation of primary and secondary alcohols and of aldehydes; the formation of 2- and 5-ketogluconate, the latter being formed in nature by Gluconobacter and Acetobacter only; the oxidation of glycols; the numerous particulate enzymes; the dual enzyme systems, particulate and soluble, for the metabolism of many of the above compounds; the enzymic mechanism of lactate and pyruvate decomposition; the formation of pyrones; the inability to grow on proteinaceous material." On phenotypic grounds, one of us has previously deduced that Acetobacter and Gluconobacter are of a common phylogenetic origin (11). The presently reported similarity of rRNA cistrons in both genera confirms this conclusion. Unfortunately, in Bergey's Manual, eighth edition (8), more weight has been given to the difference in flagellation than to the numerous physiological, biochemical, and enzymic similarities taken together, and both genera were separated: Gluconobacter as Genus IV in the polarly flagellated family Pseudomonadaceae and Acetobacter as a genus of uncertain affiliation among the aerobic, gram-negative rods and cocci. Our evidence shows that the use of the type of flagellation as a dominant criterion to separate Acetobacter and Gluconobacter into different families is untenable. In fact, there is additional evidence from other taxa that the importance of the type of flagellation in establishing the higher ranks in bacterial taxonomy should be reevaluated and reduced to a lower level: thus, polarly flagellated and peritrichous species occur in Chromobacter. ium, Janthinobacterium, Aeromonas and Vibrio; there is considerable phenotypic and genetic similarity between the peritrichous Enterobacteriaceae and the polarly flagellated Vibrionaceae; and there is considerable phenotypic and genetic similarity between the peritrichous $(\mathrm{Al}$ caligenes eutrophus, etc.) and the polarly ( $P$. palleronii, etc.) flagellated hydrogen-oxidizing bacteria and between the peritrichous and the subpolarly flagellated rhizobia.

To do justice to the considerable similarities shared by Acetobacter and Gluconobacter, it seems unavoidable to unite them in the family Acetobacteraceae Henrici 1939, 99 (26) with Acetobacter Beijerinck 1898,215 as the type genus. The description of this family is as follows. Cells ellipsoidal to rod-shaped, occurring singly or in pairs or in chains. Involution forms may occur and may be spherical, elongated, swollen, club shaped, curved, branched, or filamentous. Motile cells are peritrichous; cells with three to eight, rarely one, polar flagella and nonmotile cells also occur. Endospores are not produced. Gram negative or gram variable. A number of strains produce 2-, 5- or 2,5-diketogluconate, or both, water-soluble brown pigments, and $\gamma$-pyrones. Catalase is usually produced. Strictly aerobic. Temperature for optimum 
growth: 25 to $30^{\circ} \mathrm{C}$. Most strains do not grow at $37^{\circ} \mathrm{C}$. The $\mathrm{pH}$ for optimum growth is 5.5 to 6.0 . Growth and acetic acid production occur at $\mathrm{pH}$ 4 to 4.5. Gelatin is not liquefied (J. De Ley and J. Swings, manuscript in preparation). A number of the common biochemical and enzymatic characteristics of the organisms cited above have been quoted from reference 12 .

Relationships of the acetic acid bacteria to other genera. Genera related to the acetic acid bacteria were detected by hybridizing rRNA from either Gluconobacter or Acetobacter with DNA from representative strains of a variety of gram-negative taxa. From previous papers $(16,19)$ and much unpublished data, we could deduce which taxa would constitute a rRNA superfamily with Acetobacter and Gluconobacter. Since reciprocal hybridizations always yield the same $T_{m(e)}$ values (within the limits of error), only a small number of strains per taxon had to be included, merely to locate the position of the genera on the map, not to determine their area shape. Table 1 shows that the strains fell into two groups: those with a $T_{m(e)}$ from 63 to $69.8^{\circ} \mathrm{C}$ and those from 57 to $61.8^{\circ} \mathrm{C}$. None of the genera tested was found to map above $70^{\circ} \mathrm{C}$, indicating that none of them had a close relationship to the acetic acid bacteria. In the former group belong Agrobacter. ium, Rhizobium, Phyllobacterium, Mycoplana, some Spirillum species (this is a heterogeneous genus), Zymomonas, Rhodopseudomonas, Beijerinckia, Paracoccus, Azotomonas fluorescens, and the misnamed $(16,19)$ organisms "Agrobacterium" aggregatum, " $A$." ferrugineum, "A." luteum, "Pseudomonas" diminuta, and "Chromobacterium" folium. All these organisms, together with Acetobacter and Gluconobacter, constitute one large rRNA superfamily (Fig. 6) at a $T_{m(e)}$ of about $66.5^{\circ} \mathrm{C}$. Many of these live in or on plants: the tumorigenic and rhizogenic Agrobacterium, the root nodule-forming $R \mathrm{hi}$ zobium, the leaf nodule-inhabiting Phyllobacterium and " $C$." folium, the acetic acid bacteria, and Zymomonas, which prefers to grow in plant saps; others (Mycoplana and Beijerinckia) have been isolated from plant sources or live in the phytosphere. All of these organisms are gram negative, and the Entner-Doudoroff pathway has been detected in most of them. Extensive comparison of their phenotypic features is difficult for lack of data. The present results suggest that more comparative information at the generic level is required. It may seem unexpected

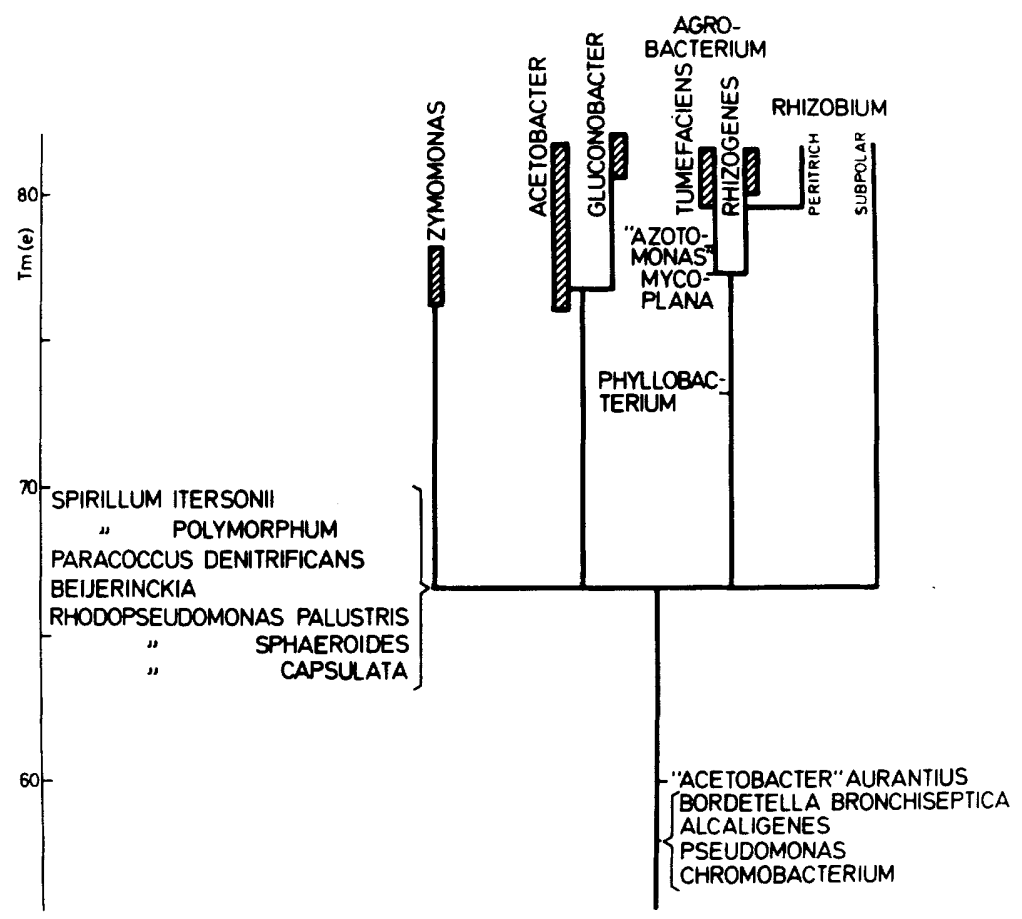

Fig. 6. Levels of $T_{m(e)}$ similarities within the rRNA superfamily consisting of the acetic acid bacteria, Zymomonas, Agrobacterium, Rhizobium, Rhodopseudomonas, Paracoccus, etc. The closest rRNA superfamilies are at an average $T_{m(e)}$ of $58^{\circ} \mathrm{C}$ and consist of Chromobacterium, Pseudomonas, Bordetella bronchiseptica, etc. (16). The data for the graph are from the present paper and from De Smedt and De Ley (19). 
that representatives of the phototrophic Rhodopseudomonas and of the chemoorganotrophic, facultatively chemolithotrophic Paracoccus denitrificans figure in this rRNA superfamily. This seems to be contrary to a widely accepted but unproven assumption among biologists that the presently living phototrophic and chemolithotrophic bacteria are descendants of a primitive, separate, phylogenetic branch of microorganisms. Our data suggest that this is not the case for Rhodopseudomonas and Paracoccus. This is strengthened by an amino acid sequence comparison of cytochromes from both genera (36). N-terminal heme-bound cytochrome $c_{550}$ of Paracoccus denitrificans is most similar to N-terminal heme-bound cytochrome $c_{2}$ of Rhodomicrobium and Rhodopseudomonas. The c-type cytochrome sequences place both genera in a portion of the evolutionary tree surrounded by strictly aerobic, obligately heterotrophic bacteria (36). There is a distinct similarity between the C-terminal heme-bound cytochrome $c_{556}$ of Agrobacterium and the C-terminal heme-bound cytochrome $c^{\prime}$ of Rhodopseudomonas (J. Van Beeumen, P. Tempst, J. Van Damme, and J. De Ley, manuscript in preparation). When the Rhodospirillaceae grow chemoorganotrophically under aerobic conditions, they are very similar to nonphotosynthetic bacteria. For example, Rhodopseudomonas sphaeroides has the Entner-Doudoroff mechanism, an almost complete shunt mechanism, and several cytoplasmic membrane-linked, sugar-oxidizing enzymes (39) very much like the acetic acid bacteria. We conclude that the rRNA superfamily of taxa as shown in Fig. 6 represents a branch of the phylogeny of the aerobic, chemoorganotrophic organisms concerned as well as a measure of taxonomic relationships at the generic and suprageneric level. Taxa belonging to the Chromobacterium, Janthinobacterium, $P$. acidovorans, $P$. solanacearum, Alcaligenes-Achromobacter, Bordetella bronchiseptica rRNA superfamily (16) group at an average low $T_{m(e)}$ level of $58^{\circ} \mathrm{C}$.

Zymomonas. Although some strains of Zymomonas can grow modestly aerobically, all strains prefer to grow anaerobically. This genus was recently extensively reviewed by Swings and De Ley (39). It is very homogeneous in spite of its wide geographic distribution. It contains but one species and two subspecies (39). Representative strains of each taxon were included. Figure 5 and Table 2 show variations on $T_{m(e)}$ and percentage of rRNA binding of $\pm 1^{\circ} \mathrm{C}$ and \pm $0.025 \%$, respectively, which data confirm the compactness of the genus. Reverse hybridizations are reported in Table 5. Zymomonas is about equidistant from Gluconobacter, Acetobacter, Rhodopseudomonas, Rhizobium, Agrobacterium, and Paracoccus [average $\Delta T_{m(e)}$ versus the homologous hybrid: $-14.5^{\circ} \mathrm{C}$ ). It clearly belongs in the same rRNA superfamily as these taxa. At first glance it may seem surprising that a largely anaerobic genus belongs in a cluster together with many strictly aerobic genera. $\mathrm{Nev}$ ertheless there are many phenotypic similarities, particularly between Zymomonas and the acetic acid bacteria (39): related ecologic niches in or on plants, joint occurrence in fermented tropical plant juices and beer, tolerance toward low pH, high ethanol or glucose concentration in the growth medium, aerobic oxidation of ethanol to acetic acid, and limited efficiency of $\mathrm{C}$ assimilation. Zymomonas is phenotypically more like Gluconobacter than Acetobacter (polar flagellation, incomplete Krebs cycle, occurrence of Entner-Doudoroff cycle, ready consumption of glucose). These considerable phenotypic and $T_{m(e)}$ similarities suggest that the ancestors of Zymomonas were aerobic organisms, closely related to the ancestors of the present acetic acid bacteria. We assume that these ancestors gave rise to the present zymomonads by loss of some Krebs cycle enzymes and perhaps also some electron transport enzymes (39).

DNA base composition of the acetic acid bacteria. The DNA base compositions of the acetic acid bacteria reported in Bergey's Manual, eighth edition (14), are almost solely derived from data obtained in this laboratory (15). In the present paper, we report a total of $116 \mathrm{G}+\mathrm{C}$ determinations, which we used to confirm and extend our previous conclusions. In Bergey's Manual, one of us (14) reported 55 to $64 \mathrm{~mol} \%$ $\mathrm{G}+\mathrm{C}$ for Acetobacter and 57 to $64 \mathrm{~mol} \% \mathrm{G}+\mathrm{C}$ for Gluconobacter. Our present range is from 51 to $65 \mathrm{~mol} \% \mathrm{G}+\mathrm{C}$ for Acetobacter and from 56 to $64 \mathrm{~mol} \% \mathrm{G}+\mathrm{C}$ for Gluconobacter. The $\mathrm{G}+\mathrm{C}$ ranges (in moles percent) for the individual species and subspecies are: $A$. aceti subsp. aceti, 55 to $60 ; A$. aceti subsp. orleanensis, 56 to $60 ; A$. aceti subsp. xylinum, 55 to $63 ; A$. acet $i$ subsp. liquefaciens, 61 to $65 ; A$. pasteurianus subsp. pasteurianus, 51 to 61 ; A. pasteurianus subsp. lovaniensis, 58; A. pasteurianus subsp. estunensis, 60 to 62; A. pasteurianus subsp. ascendens, 54 to 56; $A$. pasteurianus subsp. paradoxus, 53; A. peroxydans, 50 to 53; Gluconobacter oxydans subsp. oxydans, 58 to 62 ; $G$. oxydans subsp. industrius, 61 to 64 ; $G$. oxydans subsp. suboxydans, 56 to 64; and G. oxydans subsp. melanogenes, 59 to 61 .

\section{ACKNOWLEDGMENTS}

J. D. L. thanks the Fonds voor Kollektief Fundamenteel Onderzoek for personnel and for research grants. We thank 
the many laboratories, institutes, and individuals who donated the strains used in this study.

\section{REPRINT REQUESTS}

Address reprint requests to: Prof. Dr. J. De Ley, Laboratorium voor Microbiologie, RUG, Ledeganckstraat 35, B-9000 Gent, Belgium.

\section{LTERATURE CITED}

1. Allen, T. C., and A. J. Riker. 1932. A rot of apple fruit caused by Phytomonas melophthora n.sp., following invasion by the apple maggot. Phytopathology 22:557571.

2. Ameyama, M., H. Fujisawa, and K. Kondò. 1965. Carbohydrate metabolism by the acetic acid bacteria. IV. On the patterns of carbohydrate oxidizabilities and their variation. J. Agric. Chem. Soc. Jpn. 39:427-435.

3. Ameyama, M., and K. Kondô. 1967. Carbohydrate metabolism by the acetic acid bacteria. VI. Characteristics of the intermediate type strains. Agric. Biol. Chem. 31: 724-737.

4. Asai, T. 1968. Acetic acid bacteria. University of Tokyo Press, Tokyo.

5. Asai, T., H. lizuka, and K. Komagata. 1964. The flagellation and taxonomy of genera Gluconobacter and Acetobacter with reference to the existence of intermediate strains. J. Gen. Appl. Microbiol. 10:95-126.

6. Bertrand, G. 1904. Etude biochimique de la bactérie du sorbose. Ann. Chim. Phys. 3:181-288.

7. Brown, A. J. 1886. On an acetic ferment which forms cellulose. J. Chem. Soc. Trans. 49:432-439.

8. Buchanan, R. E., and N. E. Gibbons (ed.). 1974. Bergey's manual of determinative bacteriology, 8 th ed. The Williams \& Wilkins Co., Baltimore.

9. Cole, M. 1959. Bacterial rotting of apple fruit. Ann. Appl. Biol. 47:601-611.

10. De Ley, J. 1958. Studies on the metabolism of Acetobac ter peroxydans. I. General properties and taxonomic position of the species. Antonie van Leeuwenhoek $\mathbf{J}$. Microbiol. Serol. 24:281-297.

11. De Ley, J. 1961. Comparative carbohydrate metabolism and a proposal for a phylogenetic relationship of the acetic acid bacteria. J. Gen. Microbiol. 24:31-50.

12. De Ley, J. 1963. Some remarks on two papers by Shimwell et al. on acetic acid bacteria. Antonie van Leeuwenhoek J. Microbiol. Serol. 29:305-307.

13. De Ley, J., and J. De Smedt. 1975. Improvements of the membrane filter method for DNA:rRNA hybridization. Antonie van Leeuwenhoek J. Microbiol. Serol. 41:287-307.

14. De Ley, J., and J. Frateur. 1974. Gluconobacter Asai 1935, p. 251-253; Acetobacter Beijerinck 1898, p. 276278. In R. E. Buchanan, and N. E. Gibbons (ed.), Bergey's manual of determinative bacteriology, 8th ed. The Williams \& Wilkins Co., Baltimore.

15. De Ley, J., and J. Schell. 1963. Deoxyribonucleic acid base composition of acetic acid bacteria. J. Gen. Microbiol. 33:243-253.

16. De Ley, J., P. Segers, and M. Gillis. 1978. Intra- and intergeneric similarities of Chromobacterium and Janthinobacterium ribosomal ribonucleic acid cistrons. Int. J. Syst. Bacteriol. 28:154-168.

17. De Ley, J., and R. Tytgat. 1970. Evaluation of membrane filter methods for DNA: DNA hybridization. Antonie van Leeuwenhoek J. Microbiol. Serol. 36:461474.

18. De Ley, J., and J. Van Muylem. 1963. Some applications of deoxyribonucleic acid base composition in bacterial taxonomy. Antonie van Leeuwenhoek J. Microbiol. Serol. 29:344-358.

19. De Smedt, J., and J. De Ley. 1977. Intra- and intergeneric similarities of Agrobacterium ribosomal ribonu- cleic acid cistrons. Int. J. Syst. Bacteriol. 27:222-240.

20. Dhanvantari, B. N., D. W. Dye, and J. M. Young. 1978. Pseudomonas pomi Cole 1959 is a later subjective synonym of Acetobacter pasteurianus (Hansen 1879) Beijerinck 1898 and Pseudomonas melophthora Allen and Riker 1932 is a nomen dubium. Int. J. Syst. Bacteriol. 28:532-537.

21. Emmerling, O. 1899. Zur Kenntniss des Sorbosebacteriums. Ber. Dtsch. Chem. Ges. 32:541-542.

22. Frateur, J. 1950. Essai sur la systématique des Acétobacters. Cellule 53:287-398.

23. Gonçalves De Lima, O., J. Otamar Falcão De Morais, and C. Larios Carmona. 1955. Nova espécie do gênero Acetobacter: A. lermae. An. Soc. Biol. Pernambuco 13: 13-17.

24. Grienenberger, J. M., and D. Simon. 1975. Structure and biosynthesis of the ribosomal ribonucleic acids from the oncogenic bacterium Agrobacterium tumefaciens. Biochem. J. 149:23-30.

25. Hall, A: N., I. Husain, K. S. Tiwari, and T. K. Walker. 1956. Nutritional requirements of Acetobacter species: inorganic ammonium salts as sources of nitrogen. $J$. Appl. Bacteriol. 19:31-35.

26. Henrici, A. T. 1939. The biology of bacteria, 2nd ed., p. 1-494. D. C. Heath and Co., Chicago.

27. Kasai, T., I. Susuki, and T. Asai. 1963. Glyoxylate oxidation in Acetobacter with reference to the formation of oxalic acid. J. Gen. Appl. Microbiol. 9:49-58.

28. Kersters, K., and J. De Ley. 1975. Identification and grouping of bacteria by numerical analysis of their electrophoretic protein patterns. J. Gen. Microbiol. 87: 333-342.

29. Kondô, K., and M. Ameyama. 1958. Carbohydrate metabolism by Acetobacter species. I. Oxidative activity for various carbohydrates. Bull. Agric. Chem. Soc. Jpn. 22:369-372.

30. Kulka, D., J. M. Preston, and T. K. Walker. 1949. Giant colonies of Acetobacter species as an aid to identification. J. Inst. Brew. 55:141-146.

31. Kulka, D., J. Singh, R. M. Nattrass, A. N. Hall, and T. K. Walker. 1958. Studies on vinegar bacteria. J. Sci. Food Agric. 8:487-492.

32. Marmur, J. 1961. A procedure for the isolation of deoxyribonucleic acid from micro-organisms. J. Mol. Biol. 3: 208-218.

33. Ruiz-Argüeso, T., and A. Rodriguez-Navarro. 1973. Gluconic acid-producing bacteria from honey bees and ripening honey. J. Gen. Microbiol. 76:211-216.

34. Ruiz-Argüeso, T., and A. Rodriguez-Navarro. 1975. Microbiology of ripening honey. Appl. Microbiol. 30: 893-896.

35. Schuch, W., and U. E. Loening. 1975. The ribosomal ribonucleic acid of Agrobacterium tumefaciens. Biochem. J. 149:17-22.

36. Schwartz, R. M., and M. O. Dayhoff. 1978. Origins of prokaryotes, eukaryotes, mitochondria and chloroplasts. Science 199:395-403.

37. Shimwell, J. L., and J. G. Carr. 1960. Derivation of nonacetifying "quasi-Acetobacters" from a true Aceto. bacter strain, and vice versa. Antonie van Leeuwenhoek J. Microbiol. Serol. 26:169-181.

38. Swings, J., and J. De Ley. 1975. Genome deoxyribonucleic acid of the genus Zymomonas Kluyver and van Niel 1936: base composition, size and similarities. Int. J. Syst. Bacteriol. 25:324-328.

39. Swings, J., and J. De Ley. 1977. The biology of Zymomonas. Bacteriol. Rev. 41:1-46.

40. Szymona, M., and M. Doudoroff. 1960. Carbohydrate metabolism in Rhodopseudomonas sphaeroides. J. Gen. Microbiol. 22:167-183.

41. Visser 't Hooft, F. 1925. Biochemische onderzoekingen over het geslacht Acetobacter. Publ. W. D. Meinema, Delft, the Netherlands. 
42. Walker, T. K., and J. Tő̈ić. 1945. Acetobacter infection. II. Studies of Acetobacter viscosum and Acetobacter acet $i$ isolated, respectively, from top-fermentation beer and yeast. J. Inst. Brew. 51:245-250.

43. Yamada, Y., K. Aida, and T. Uemura. 1969. Enzymatic studies on the oxidation of sugar and sugar alcohol. $\mathrm{V}$. Ubiquinone of acetic acid bacteria and its relation to classification of genera Gluconobacter and Acetobacter especially on the so-called intermediate strains. J. Gen. Microbiol. 15:181-196.

44. Yamada, Y., Y. Okada, and K. Kondó. 1976. Isolation and characterization of "polarly flagellated intermediate strains" in acetic acid bacteria. J. Gen. Appl. Microbiol. 22:237-245. 